\title{
Effects of Fertilization and Microbial Inoculants Applied at Transplanting on the Growth of Mexican Fan Palm and Queen Palm
}

\author{
Timothy K. Broschat ${ }^{1}$ and Monica L. Elliott
}

\begin{abstract}
ADDITIONAL INDEX WORDs. mycorrhizae, Washingtonia robusta, Syagrus romanzoffiana

Summary. Container-grown mexican fan palm (Washingtonia robusta) and queen palm (Syagrus romanzoffiana) transplanted into a field nursery having phosphorus (P)-sufficient and P-deficient soils were treated at the time of planting with four commercial microbial inoculants (each containing arbuscular mycorrhizal fungi, alone or with other microbial components or fertilizers), two fertilizers, or nothing (control). All but the control palms received applications of an $8 \mathrm{~N}-0.9 \mathrm{P}-10 \mathrm{~K}$ palm fertilizer every 3 months for 2 years. None of the treatments improved growth over the control in the P-deficient soil. In the P-sufficient soil, none of the microbial inoculants improved growth over that of similarly fertilized noninoculated palms. Discrepancies were observed regarding nonmycorrhizal fungi and bacteria present in the microbial inoculant products. The type and quantity of these microbes listed on the labels of the microbial inoculant products did not necessarily match the type and quantity actually detected in the products.
\end{abstract}

$\mathrm{T}$ he use of commercial microbial inoculants, especially arbuscular mycorrhizal (AM) fungi, has been widely promoted for woody plants, including palms (Arecacaeae), transplanted into the landscape. AM fungi may promote plant health and development and may provide a means for reducing inorganic (chemical) fertilizers (Gianinazzi and Vosátka, 2004). Compatible AM fungal/plant root associations result in a symbiotic relationship, with the plant providing carbon for the fungus and the fungus providing phosphate for the plant (Harrison, 1997). Although all palm species surveyed to date have been shown to have AM fungal associations under natural conditions (e.g., Carillo et al., 2002; Fisher and Jayachandran, 1999, 2005; Núñez-Castillo and Alvarez-Sánchez, 2003; St. John, 1988), beneficial effects due to AM fungal inoculations of palms have generally been demonstrated in sterile soils or potting substrates (Blal et al.,

This project was funded in part by a grant from Plant Health Care, Inc. (Pittsburgh, PA) and by the Florida Agricultural Experiment Station.

The authors wish to thank Elizabeth DesJardin, Anita Durden, William Latham, and Susan Thor for their assistance in this study.

University of Florida, Fort Lauderdale Research and Education Center, 3205 College Avenue, Davie, FL 33314

${ }^{1}$ Corresponding author. E-mail: tkbr@ufl.edu.
1990; Jaizme-Vega and Diaz-Perez, 1999; Morte and Honrubia, 2002; Widiastuti and Tahardi, 1993), Pdeficient soils (Sanni, 1981), or both (Fisher and Jayachandran, 2008; Janos, 1977).

A number of the commercial products being marketed for palms also contain beneficial fungi other than AM fungi, beneficial bacteria, humic acid, fulvic acid, vitamins, and biostimulants such as kelp (Ascophylum nodosum) extract. The beneficial interactions of bacteria and AM fungi are multifaceted, ranging from a direct effect on the AM fungi to increased nutrient uptake due to increased root mass (Artursson et al., 2006).

In addition to containing beneficial microbes, many of these commercial products contain inorganic or organic fertilizer sources. Blal et al. (1990) and Sanni (1981) found that african oil palm (Elaeis guineensis)micropropagated plantlets and seedlings grew better with AM fungi plus fertilizers than with AM fungi alone. Other researchers have demonstrated that the nutrient content of palms colonized by AM fungi was increased when the palms also received fertilizer (Al-Whaibi and Khaliel, 1994; Bovi et al., 2000).

Most microbial inoculants are intended for commercial production of palms in containers, field nurseries, or landscapes that have nonsterile soils and are fertilized regularly. Yet, there is no published research on the performance of these products under such conditions. The purpose of this study was to determine the effects of several commercially available microbial inoculants on the growth of palms transplanted into a field nursery.

\section{Materials and methods}

Transplant treatments. Mexican fan palm and queen palm previously growing in 3 -gal containers were obtained from a local nursery and were field transplanted on 2-3 Feb. 2006 in Davie, FL (lat. $26^{\circ} 5^{\prime} 1.09^{\prime \prime} \mathrm{N}$, long. $\left.80^{\circ} 14^{\prime} 39.16^{\prime \prime} \mathrm{W}\right)$. The soil was a Margate fine sand (Siliceous, hyperthermic Mollic Psammaquent) with a cation exchange capacity of $15 \mathrm{mmol} \cdot \mathrm{kg}^{-1}$ and a $\mathrm{pH}$ of 5.4. The experiment was set up as a randomized complete block design within each species plot with 10 replicate palms per species and treatment. About half of each species plot was located on natural soil pockets that appeared to be deficient in $\mathrm{P}$ (Mehlich I $P=0.26 \mathrm{ppm}, \mathrm{n}=3$ ), while the remaining half appeared to be $\mathrm{P}$ sufficient $(0.32 \mathrm{ppm}, \mathrm{n}=3)$. Although these soil $\mathrm{P}$ levels are considered to be very low for both soil plots (Council on Soil Testing and Plant Analysis, 1992), the bahiagrass (Paspalum notatum) and weed groundcover grew luxuriantly on the P-sufficient

\begin{tabular}{llll}
\hline $\begin{array}{l}\text { Units } \\
\text { To convert U.S. to SI, } \\
\text { multiply by }\end{array}$ & U.S. unit & SI unit & $\begin{array}{l}\text { To convert SI to U.S., } \\
\text { multiply by }\end{array}$ \\
\hline 29.5735 & $\mathrm{fl} \mathrm{oz}$ & $\mathrm{mL}$ & 0.0338 \\
0.3048 & $\mathrm{ft}$ & $\mathrm{m}$ & 3.2808 \\
3.7854 & gal & $\mathrm{L}$ & 0.2642 \\
2.54 & inch(es) & $\mathrm{cm}$ & 0.3937 \\
16.3871 & inch & $\mathrm{cm}^{3}$ & 0.0610 \\
1.1209 & $\mathrm{lb} / \mathrm{acre}$ & $\mathrm{kg} \cdot \mathrm{ha}^{-1}$ & 0.8922 \\
1 & micron & $\mu \mathrm{m}$ & 1 \\
25.4 & mil & $\mu \mathrm{m}$ & 0.0394 \\
28.3495 & $\mathrm{oz}$ & $\mathrm{g}$ & 0.0353
\end{tabular}


soil, but were sparse, stunted, and reddish in color on the $\mathrm{P}$-deficient soil. Soil $\mathrm{P}$ requirements for palms are unknown. Because transitions between P-deficient and P-sufficient pockets of soil were abrupt, by plotting palm height and the presence or absence of P-deficient groundcovers on a map of the experimental plot, palms were easily assigned to one soil type or another a posteriori for covariate analysis.

Palms were planted on 12 -ft centers and received about 0.5 inch of water from overhead irrigation every other day during establishment (20 weeks) and twice per week thereafter. Rainfall data (65 inches in the first year and 73 inches during the second) were obtained from the Florida Automated Weather Network (FAWN) station located about $400 \mathrm{~m}$ from the plot (University of Florida, 2008). A circular area with a diameter of $\approx 1 \mathrm{~m}$ was maintained weed-free around each palm with glyphosate.

Transplant field treatments consisted of: 1) no microbial inoculant or fertilizer (control); 2) 8N-0.9P-10K (Nurserymen's Sure Gro, Vero Beach, FL) palm fertilizer [palm fertilizers contain more potassium $(\mathrm{K})$, magnesium $(\mathrm{Mg})$, iron $(\mathrm{Fe})$, and manganese (Mn) than those used on other crops (Broschat, 2005)] broadcast uniformly to the $1-\mathrm{m}^{2}$ area surrounding the palm at the recommended maintenance rate of $73 \mathrm{~g} \cdot \mathrm{m}^{-2}$ (8N-0.9P-10K low rate); 3 ) MycoS$\operatorname{tim}^{\mathrm{TM}}$ (Organic Laboratories, Stuart, FL) incorporated into the top 6 inches of backfill at the label rate of $57 \mathrm{~g}$ per palm plus $73 \mathrm{~g} \cdot \mathrm{m}^{-2}$ of $8 \mathrm{~N}-$ $0.9 \mathrm{P}-10 \mathrm{~K}$ palm fertilizer broadcast as in treatment 2 ; 4) Bio/Organics ${ }^{\mathrm{TM}}$ Endomycorrhizal Inoculant (Bio/ Organics, La Pine, OR) incorporated into the top 6 inches of backfill at the label rate of 5 g per palm plus the $8 \mathrm{~N}-$ $0.9 \mathrm{P}-10 \mathrm{~K}$ palm fertilizer broadcast at $73 \mathrm{~g} \cdot \mathrm{m}^{-2}$ as in treatment $\left.2 ; 5\right) \mathrm{PHC}^{\circledR}$ Palm Saver ${ }^{\circledR}$ (Plant Health Care, Pittsburgh) $6 \mathrm{~N}-1.3 \mathrm{P}-5 \mathrm{~K}$ incorporated into the top 6 inches of backfill at the label rate of $170 \mathrm{~g}$ per palm (PHC Palm Saver with microbes); 6) PHC Palm Saver 6N-1.3P-5K without microbes applied as in treatment 5 at 170 g per palm (PHC Palm Saver without microbes); 7) DieHard ${ }^{\mathrm{TM}}$ Palm 6N-1.3P-5K (Horticultural Alliance, Sarasota, FL) incorporated into the top 6 inches of backfill at the rate of $170 \mathrm{~g}$ per palm (DieHard Palm); and 8 ) the $8 \mathrm{~N}-0.9 \mathrm{P}-10 \mathrm{~K}$ palm fertilizer incorporated into the top 6 inches of backfill at the rate of 127 g per palm, equivalent to the $\mathrm{N}$ content of PHC Palm Saver and DieHard Palm (8N-0.9P-10K high rate). The two PHC products were supposed to be identical to each other, except for the microbial component. The PHC Palm Saver with microbes is the commercially available product. The PHC Palm Saver without microbes was formulated by $\mathrm{PHC}$ specifically for this study.

All treatments except for the control received broadcast applications of the $8 \mathrm{~N}-0.9 \mathrm{P}-10 \mathrm{~K}$ palm fertilizer around each palm at a rate of $73 \cdot \mathrm{g} \cdot \mathrm{m}^{-2}$ at 3 months after transplanting and every 3 months thereafter as a standard maintenance practice (Broschat, 2005). Total palm height, as measured to the tip of the longest fully extended leaf, and the number of living leaves (a measure of palm quality) were recorded at the time of planting and after 6 and 24 months when the experiment was ended.

All data were analyzed by analysis of covariance and analysis of variance, with mean separations by the WallerDuncan k-ratio method and contrasts among treatments using PROC GLM (SAS version 9.1; SAS Institute, Cary, NC).

Microbial analysis. Table 1 lists the commercially available products used in this study that were supposed to contain microbes, along with the type and quantity of microbes stated on the product label. The $8 \mathrm{~N}-$ $0.9 \mathrm{P}-10 \mathrm{~K}$ palm fertilizer used in treatments 2 and 8 contains macroand micronutrients derived from chemical fertilizer sources. The PHC Palm Saver products contain humic acid, and macro- and micronutrients derived from urea-formaldehyde, blood meal, feather meal, hydrolyzed fish meal, potassium sulfate, triple superphosphate, iron sucrate, magnesium sulfate, magnesium sucrate, manganese sucrate, and zinc sucrate. MycoStim contains sea kelp, humic acid, fulvic acid, amino acids, and vitamin B complex. DieHard Palm contains humic acid, fulvic acid, vitamins $(\mathrm{B}, \mathrm{B} 2, \mathrm{~B} 3, \mathrm{~B} 6, \mathrm{~B} 12, \mathrm{C}, \mathrm{K}$, and biotin), sea kelp extract, yucca ( $(u c c a$ schidigera) extract, acrylamide copolymers, and macro- and micronutrients derived from chemical fertilizers. Based on the label associated with the product, Bio/Organics contains only microbes.

Before planting, an analysis of culturable microbes was completed on all fertilizers and microbial inoculants, soil from the field area, and palm material. For fertilizer and microbial inoculant products, $1 \mathrm{~g}$ of material was randomly obtained from the source container and was placed in $5 \mathrm{~mL}$ of potassium phosphate saline buffer (PSB) in a $50-\mathrm{mL}$ sterile tube. There were three replicate samples per material. The suspension was vortexed and shaken for $5 \mathrm{~min}$ at 250 rpm on a rotary shaker.

A 10-fold dilution series was completed after shaking, with dilution aliquots spread plated onto the following media for enumeration: a) solidified $10 \%$ tryptic soy broth (10\% TSBA) for total aerobic bacteria;

Table 1. Type and quantity of microbes reported on the label to be present in microbial transplant treatment products that were incorporated the backfill of transplanted queen palm and mexican fan palm.

\begin{tabular}{lrrccc}
\hline & & \multicolumn{4}{c}{ Spores or cfu (no./g) } \\
\cline { 3 - 6 } Treatment & $\begin{array}{c}\text { Rate } \\
(\mathbf{g})^{\mathrm{y}}\end{array}$ & $\begin{array}{c}\text { AM } \\
\text { fungi }^{\mathrm{x}}\end{array}$ & $\begin{array}{c}\text { ETM } \\
\text { fungi }^{\mathrm{x}}\end{array}$ & $\begin{array}{c}\text { Nonmycorrhizal } \\
\text { fungi }\end{array}$ & Bacteria $^{\mathrm{w}}$ \\
\hline PHC Palm & 170 & 1.6 & 0 & 0 & $1.1 \times 10^{5}$ \\
Saver with microbes $^{\mathrm{w}}$ & & & & & \\
MycoStim $^{\mathrm{v}}$ & 57 & 220.0 & $2.4 \times 10^{5}$ & 220 & 0 \\
Bio/Organics & 5 & 50.0 & 0 & 0 & 0 \\
DieHard Palm $^{\mathrm{w}}$ & 170 & 6.0 & 0 & $1.5 \times 10^{6}$ & $1.0 \times 10^{6}$ \\
\hline
\end{tabular}

${ }^{\mathrm{z}} 1$ spore or cfu per gram $=28.3495$ spores or cfu per ounce.

${ }^{\mathrm{y}} \mathrm{l} \mathrm{g}=0.0353 \mathrm{oz}$.

${ }^{\mathrm{x}} \mathrm{AM}$ fungi = arbuscular mycorrhizal fungi, ETM fungi = ectomycorrhizal fungi.

wBased on the labels associated with the product, PHC Palm Saver with microbes (Plant Health Care, Pittsburgh, PA) contains Bacillus (heat-tolerant spore-producing bacteria) and DieHard Palm (Horticultural Alliance, Sarasota, FL) contains Bacillus, Pseudomonas, and Streptomyces (actinomycete).

'Organic Laboratories, Stuart, FL.

"Bio/Organics, La Pine, OR. 
b) S-1 medium for fluorescent pseudomonads (Gould et al., 1985); c) Difco Actinomycete Isolation $\mathrm{Me}$ dium (AIM) for actinomycetes (Fisher Scientific, Pittsburgh); and d) 1/5 strength Difco potato dextrose agar (1/5 PDA) for non-AM fungi. The dilutions then were placed in an $80^{\circ} \mathrm{C}$ water bath for $10 \mathrm{~min}$ and were aliquots spread on 10\% TSBA to enumerate heat-tolerant bacteria. The $10 \%$ TSBA and AIM were supplemented with $100 \mu \mathrm{g} \cdot \mathrm{mL}^{-1}$ cycloheximide to inhibit fungi, and the $1 / 5$ PDA was supplemented with 100 $\mu \mathrm{g} \cdot \mathrm{mL}^{-1}$ streptomycin sulfate and $50 \mu \mathrm{g} \cdot \mathrm{mL}^{-1}$ rifampicin to inhibit bacteria. All plates were incubated at $28^{\circ} \mathrm{C}$ in the dark and colony-forming units per gram of material were determined.

Soil samples were obtained using a $1.0-\mathrm{cm}$-diameter soil probe to a depth of $10 \mathrm{~cm}$. Four cores were collected from each of four field quadrants, with the cores thoroughly mixed and sifted through a $1-\mathrm{mm}$ sieve to separate root material from soil. Soil ( $\mathrm{lg}$ ) was placed in $5 \mathrm{~mL}$ of PSB in a $50-\mathrm{mL}$ sterile tube, and was vortexed and shaken for $5 \mathrm{~min}$ at 250 $\mathrm{rpm}$. An additional $1 \mathrm{~g}$ of soil was placed in a container and was dried at $60{ }^{\circ} \mathrm{C}$ for $24 \mathrm{~h}$ to obtain dry weight. A dilution series was completed and plated as described.

Root samples were obtained for each palm species by removing the palm from the potting mix and shaking the palm with vigor to remove as much of the potting mix as possible. Roots were cut at the stem-root interface. About $5 \mathrm{~g}$ of smaller root pieces (second or third order) were randomly selected, placed in $100 \mathrm{~mL}$ of PBS in a $250-\mathrm{mL}$ sterile flask and shaken for $5 \mathrm{~min}$ at $250 \mathrm{rpm}$. After dilution plating, root material was retrieved from the flask and dried at $60{ }^{\circ} \mathrm{C}$ for 24 h to obtain dry weight. There were four replicate palms sampled for each palm species. Also at planting, the remaining root material from each palm sample was shipped overnight to Plant Health Care to determine level of colonization by AM fungi using the ink and vinegar staining method (Vierheilig et al., 1998).

At 24 months, when the experiment was ended, roots from three replicate palms of each species from P-sufficient and P-deficient soil were obtained from the control treatment, the PHC Palm with microbes treatment, and the DieHard Palm treatment. Second and third order roots that were just below the soil surface within a 12-inch radius from the palm were removed for processing. Roots were washed thoroughly, and a subset of roots that were $1 \mathrm{~mm}$ or less in diameter were selected and stained using the ink (Schaeffer black) and vinegar method. For each sample, a subsample of processed roots were randomly selected and examined using the magnified intersections method (McGonigle et al., 1990). At least 100 intersections were examined per sample for presence of hyphae, arbuscules, or vesicles.

\section{Results and discussion}

The quantity of non-AM fungi and bacteria we detected in the soil, palm roots, fertilizer, and microbial inoculants at transplanting is shown in Table 2. All five groups of microbes were detected in the soil and on the palm roots. As expected, the $8 \mathrm{~N}-$ $0.9 \mathrm{P}-10 \mathrm{~K}$ inorganic fertilizer was essentially free of bacteria and fungi. We did not detect fluorescent pseuodomonads in any of the microbial inoculants. Bio/Organics was only supposed to contain AM fungi (see Table 1), but we detected bacteria and non-AM fungi in this product (Table 2). We detected the least number of bacteria and non-AM fungi in the DieHard Palm material (Table 2), which should have contained the greatest number of each (see Table 1). Both PHC Palm Saver products (with microbes and without microbes) contained microbes (Table 2 ), although one should have been microbe free. The PHC Palm Saver product without microbes was specifically produced for use in this experiment, and the batch sheet for this fertilizer clearly has the microbial component crossed out. These results illustrate that quality control and/or survival of introduced non-AM fungi and bacteria can be an issue when using products claiming to contain these microorganisms - a problem that has been observed before with

Table 2. Type and quantity of bacteria and nonmycorrhizal fungi detected in the transplant material treatments on the roots of queen palm and mexican fan palm and in the soil before transplanting the palms in the field. Values are means of three (transplant treatments) or four (roots and soil) replicates. Root and soil values are based on dry weights.

\begin{tabular}{|c|c|c|c|c|c|}
\hline \multirow[b]{2}{*}{ Sample material ${ }^{\mathrm{y}}$} & \multicolumn{5}{|c|}{ Colony forming units $(\mathrm{no} . / \mathrm{g})^{\mathrm{z}}$} \\
\hline & $\begin{array}{c}\text { Total } \\
\text { bacteria }\end{array}$ & $\begin{array}{c}\text { Fluorescent } \\
\text { pseudomonads }\end{array}$ & Actinomycetes & $\begin{array}{c}\text { Heat-tolerant } \\
\text { bacteria }\end{array}$ & $\begin{array}{c}\text { Nonmycorrhizal } \\
\text { fungi }\end{array}$ \\
\hline Soil & $2.1 \times 10^{6}$ & $4.3 \times 10^{2}$ & $1.7 \times 10^{6}$ & $1.9 \times 10^{5}$ & $4.2 \times 10^{4}$ \\
\hline Queen palm roots & $1.2 \times 10^{8}$ & $7.4 \times 10^{5}$ & $5.5 \times 10^{6}$ & $1.4 \times 10^{6}$ & $1.2 \times 10^{6}$ \\
\hline Mexican fan palm roots & $1.1 \times 10^{8}$ & $4.4 \times 10^{6}$ & $7.1 \times 10^{6}$ & $9.1 \times 10^{5}$ & $6.5 \times 10^{5}$ \\
\hline $8 \mathrm{~N}-0.9 \mathrm{P}-10 \mathrm{~K}$ fertilizer & $8.0 \times 10^{1}$ & 0 & 0 & 0 & 0 \\
\hline $\begin{array}{l}\text { PHC Palm Saver } \\
\text { without microbes }\end{array}$ & $1.2 \times 10^{3}$ & 0 & $1.6 \times 10^{2}$ & $8.6 \times 10^{2}$ & $2.3 \times 10^{3}$ \\
\hline MycoStim & $6.6 \times 10^{4}$ & 0 & $1.4 \times 10^{4}$ & $2.6 \times 10^{4}$ & $1.8 \times 10^{3}$ \\
\hline Bio/Organics & $4.0 \times 10^{5}$ & 0 & $6.6 \times 10^{4}$ & $1.0 \times 10^{5}$ & $4.9 \times 10^{3}$ \\
\hline DieHard Palm & $4.0 \times 10^{2}$ & 0 & 0 & 0 & 0 \\
\hline
\end{tabular}

${ }^{2} 1$ cfu per gram $=28.3495$ cfu per ounce.

yPC Palm Saver (Plant Health Care, Pittsburgh, PA), MycoStim (Organic Laboratories, Stuart, FL), Bio/Organics (Bio/Organics, La Pine, OR), DieHard Palm (Horticultural Alliance, Sarasota, FL). 
unregulated inoculants (Elliott and Broschat, 2002; Lupwayi et al., 2000).

There were no significant differences among treatments at the time of planting, therefore initial interplant size differences could be ruled out as a significant source of variation. No growth differences were apparent until 6 months after transplanting. Across all treatments, palms of both species growing in the P-deficient soil were significantly shorter at 6 and 24 months than those growing in P-sufficient soil (Tables 3 and 4). Across all treatments, the number of leaves per palm was significantly greater for mexican fan palm at 6 and 24 months in the P-sufficient soil compared with the P-deficient soil, but only at 24 months for queen palm. Across both soils, there was a significant soil $P$ status $\times$ treatment interaction for queen palm height at 6 months, but not at 24 months. There were no interactions for queen palm leaf number at either date. There also were no interactions between soil $\mathrm{P}$ status and treatment for mexican fan palm for either height or leaf number at 6 or 24 months.

At 6 months, there were no significant transplant treatment differences in plant height or number of leaves for either species growing in the P-deficient soil (Tables 3 and 4).
However, on the P-sufficient soil, palm height and number of leaves differed significantly among treatments for mexican fan palm, and palm height differed significantly for queen palm. Palm height was lowest for control, $8 \mathrm{~N}-0.9 \mathrm{P}-10 \mathrm{~K}$ low rate-, and DieHard Palm-treated mexican fan palm, with the number of leaves showing similar trends. For queen palm, the control palms and DieHard Palm-treated palms were the shortest. In both species, palms treated at transplanting with PHC Palm Saver with microbes had equivalent height and leaf numbers to those treated with PHC Palm Saver without microbes and the $8 \mathrm{~N}-0.9 \mathrm{P}-10 \mathrm{~K}$ palm fertilizer incorporated into the backfill at an equivalent $\mathrm{N}$ rate to the PHC products $(8 \mathrm{~N}-0.9 \mathrm{P}-10 \mathrm{~K}$ high rate).

At 24 months, there were no significant differences among transplant treatments for mexican fan palm height or number of leaves in the Pdeficient soil, whereas on P-sufficient soil, those treated at transplanting with $8 \mathrm{~N}-0.9 \mathrm{P}-10 \mathrm{~K}$ high rate were significantly taller than control palms or those receiving $8 \mathrm{~N}-0.9 \mathrm{P}-10 \mathrm{~K}$ low rate (Table 3 ). For queen palm in Psufficient soil, plant height was greater for $8 \mathrm{~N}-0.9 \mathrm{P}-10 \mathrm{~K}$ low rate treatment than for control, $\mathrm{PHC}$
Palm Saver without microbes, or DieHard Palm-treated palms (Table 4). The number of leaves was unaffected by transplant treatment for either species on either soil.

Broadcasting $73 \mathrm{~g}$ of the $8 \mathrm{~N}-$ $0.9 \mathrm{P}-10 \mathrm{~K}$ palm fertilizer over $1 \mathrm{~m}^{2}$ around a palm is recommended for the maintenance of palms in Florida (Broschat, 2005), but this recommendation does not appear to be appropriate for palms recently transplanted from containers. Because the root systems of such palms are largely confined to the container volume, which has a top surface area of only $0.05 \mathrm{~m}^{2}$, these palms were exposed to only about $3.65 \mathrm{~g}\left(73 \mathrm{~g} \times 0.05 \mathrm{~m}^{2}\right)$ of fertilizer when the palms were transplanted. The high $\mathrm{N}$ requirements of palms growing in pine bark-based potting substrates (Ogden et al., 1987) undoubtedly also increased the amount of $\mathrm{N}$ required during the establishment phase. When the $8 \mathrm{~N}-0.9 \mathrm{P}-10 \mathrm{~K}$ palm fertilizer was incorporated into the backfill at the higher $\mathrm{N}$ rate, the growth of mexican fan palm was greater in the P-sufficient soil, even though the same maintenance fertilizer was applied after 3 months and for the duration of the experiment. Thus, the amount of fertilizer applied at transplanting did have a lasting effect on mexican

Table 3. Effects of transplant fertilizer and microbial inoculant treatments on the height and number of leaves of mexican fan palm growing in phosphorus $(\mathrm{P})$-deficient and $\mathrm{P}$-sufficient soils at 6 and 24 months following transplanting $(\mathrm{n}=\mathbf{1 0})$.

\begin{tabular}{|c|c|c|c|c|c|c|c|c|}
\hline \multirow[b]{3}{*}{ Treatment $^{\mathrm{z}}$} & \multicolumn{4}{|c|}{6 months } & \multicolumn{4}{|c|}{24 months } \\
\hline & \multicolumn{2}{|c|}{ P deficient } & \multicolumn{2}{|c|}{ P sufficient } & \multicolumn{2}{|c|}{ P deficient } & \multicolumn{2}{|c|}{ P sufficient } \\
\hline & $\begin{array}{c}\mathrm{Ht} \\
(\mathrm{cm})^{\mathrm{y}}\end{array}$ & $\begin{array}{c}\text { Leaves } \\
\text { (no.) }\end{array}$ & $\begin{array}{c}\text { Ht } \\
(\mathrm{cm})\end{array}$ & $\begin{array}{c}\text { Leaves } \\
\text { (no.) }\end{array}$ & $\begin{array}{c}\mathrm{Ht} \\
(\mathrm{cm})\end{array}$ & $\begin{array}{c}\text { Leaves } \\
\text { (no.) }\end{array}$ & $\begin{array}{c}\mathrm{Ht} \\
(\mathrm{cm})\end{array}$ & $\begin{array}{c}\text { Leaves } \\
\text { (no.) }\end{array}$ \\
\hline 1. Control & 70.3 & 6.3 & $72.3 \mathrm{e}^{\mathrm{x}}$ & $6.0 \mathrm{~d}$ & 84.3 & 4.7 & $123.0 \mathrm{c}$ & 12.1 \\
\hline $2.8 \mathrm{~N}-0.9 \mathrm{P}-10 \mathrm{~K}$ low & 69.7 & 6.5 & $68.3 \mathrm{e}$ & $6.0 \mathrm{~cd}$ & 116.6 & 11.8 & $145.0 \mathrm{bc}$ & 15.6 \\
\hline 3. MycoStim $+8 \mathrm{~N}-0.9 \mathrm{P}-10 \mathrm{~K}$ low ${ }^{\mathrm{w}}$ & 71.8 & 5.7 & $83.3 \mathrm{abc}$ & $7.3 \mathrm{bcd}$ & 114.2 & 11.5 & $160.5 \mathrm{ab}$ & 18.0 \\
\hline $\begin{array}{l}\text { 6. PHC Palm Saver without } \\
\text { microbes }\end{array}$ & 77.5 & 6.8 & $93.5 \mathrm{a}$ & $8.3 \mathrm{ab}$ & 118.0 & 8.0 & $164.2 \mathrm{ab}$ & 16.3 \\
\hline 7. DieHard Palm & 69.8 & 6.2 & 78.2 cde & $7.2 \mathrm{bcd}$ & 119.8 & 11.8 & $162.6 \mathrm{ab}$ & 17.6 \\
\hline $8.8 \mathrm{~N}-0.9 \mathrm{P}-10 \mathrm{~K}$ high $^{\mathrm{w}}$ & 68.3 & 5.7 & $87.3 \mathrm{ab}$ & $8.4 \mathrm{a}$ & 132.8 & 13.6 & $179.6 \mathrm{a}$ & 20.2 \\
\hline \multicolumn{9}{|l|}{ Contrasts } \\
\hline 2 vs. 3,4 & NS & NS & 0.008 & NS & NS & NS & NS & NS \\
\hline 5,7 vs. 6,8 & NS & NS & NS & NS & NS & NS & NS & NS \\
\hline 5 vs. 6 & NS & NS & NS & NS & NS & NS & NS & NS \\
\hline 1 vs. $2-8$ & NS & NS & 0.021 & 0.007 & 0.034 & 0.021 & 0.0014 & 0.016 \\
\hline
\end{tabular}


Table 4. Effects of transplant fertilizer and microbial inoculant treatments on the height and number of leaves of queen palm growing in phosphorus $(\mathrm{P})$-deficient and $\mathrm{P}$-sufficient soils at 6 and 24 months following transplanting $(\mathrm{n}=10)$.

\begin{tabular}{|c|c|c|c|c|c|c|c|c|}
\hline \multirow[b]{3}{*}{ Treatment $^{\mathrm{z}}$} & \multicolumn{4}{|c|}{6 months } & \multicolumn{4}{|c|}{24 months } \\
\hline & \multicolumn{2}{|c|}{ P deficient } & \multicolumn{2}{|c|}{ P sufficient } & \multicolumn{2}{|c|}{ P deficient } & \multicolumn{2}{|c|}{ P sufficient } \\
\hline & $\begin{array}{l}\mathrm{Ht} \\
(\mathrm{cm})^{\mathrm{y}}\end{array}$ & $\begin{array}{l}\text { Leaves } \\
\text { (no.) }\end{array}$ & $\begin{array}{c}\mathrm{Ht} \\
(\mathrm{cm})\end{array}$ & $\begin{array}{l}\text { Leaves } \\
\text { (no.) }\end{array}$ & $\begin{array}{c}\mathrm{Ht} \\
(\mathrm{cm})\end{array}$ & $\begin{array}{c}\text { Leaves } \\
\text { (no.) }\end{array}$ & $\begin{array}{c}\mathrm{Ht} \\
(\mathrm{cm})\end{array}$ & $\begin{array}{c}\begin{array}{c}\text { Leaves } \\
\text { (no.) }\end{array} \\
\end{array}$ \\
\hline 1. Control & 124.4 & 4.6 & $118.3 b^{x}$ & 4.7 & 277.1 & 4.9 & $389.4 \mathrm{c}$ & 6.0 \\
\hline $2.8 \mathrm{~N}-0.9 \mathrm{P}-10 \mathrm{~K}$ low ${ }^{\mathrm{w}}$ & 117.0 & 4.7 & $128.4 \mathrm{ab}$ & 5.1 & 293.8 & 5.0 & $443.1 \mathrm{a}$ & 6.1 \\
\hline 3. MycoStim $+8 \mathrm{~N}-0.9 \mathrm{P}-10 \mathrm{~K}$ low & 106.4 & 4.6 & $144.4 \mathrm{a}$ & 4.4 & 285.5 & 5.8 & $433.7 \mathrm{abc}$ & 6.4 \\
\hline $\begin{array}{l}\text { 6. PHC Palm Saver without } \\
\text { microbes }\end{array}$ & 123.4 & 4.8 & $129.6 \mathrm{ab}$ & 5.0 & 344.0 & 7.0 & $394.1 \mathrm{bc}$ & 7.2 \\
\hline 7. Diehard Palm & 121.0 & 4.8 & $119.8 \mathrm{~b}$ & 4.8 & 296.5 & 5.6 & 394.7 bc & 7.0 \\
\hline 8. $8 \mathrm{~N}-0.9 \mathrm{P}-10 \mathrm{~K}$ high $^{\mathrm{w}}$ & 128.5 & 4.5 & $131.2 \mathrm{ab}$ & 4.3 & 303.5 & 5.8 & $417.8 \mathrm{abc}$ & 6.2 \\
\hline \multicolumn{9}{|l|}{ Contrasts } \\
\hline 2 vs. 7,8 & NS & NS & NS & 0.013 & NS & NS & NS & NS \\
\hline 5,7 vs. 6,8 & NS & NS & 0.043 & NS & NS & NS & NS & NS \\
\hline 5 vs. 6 & NS & NS & NS & NS & NS & NS & NS & NS \\
\hline 1 vs. $2-8$ & NS & NS & NS & NS & NS & NS & NS & NS \\
\hline
\end{tabular}

fan palm growth. A similar effect was not observed with queen palm.

The addition of microbe-only inoculants (MycoStim or Bio/ Organics) in the backfill to mexican fan palms fertilized with a low rate of $8 \mathrm{~N}-0.9 \mathrm{P}-10 \mathrm{~K}$ at transplanting did significantly increase palm height over the use of $8 \mathrm{~N}-0.9 \mathrm{P}-10 \mathrm{~K}$ alone at 6 months, but not at 24 months (Table 3 ). However, these treatments were not significantly different from the $8 \mathrm{~N}-0.9 \mathrm{P}-10 \mathrm{~K}$ high rate treatment incorporated into the backfill.

For treatments receiving equivalent high rates of $\mathrm{N}$ but with or without microbial inoculants (treatments 5-8), no significant differences were observed for either soil type or growth parameter for either palm species on either date (contrasts shown in Table 3 and 4). There were no significant differences between the PHC Palm Saver products (with microbes versus without microbes) for either date, growth parameter, or palm species (Tables 3 and 4). Overall, it appears that growth responses observed in these palms may be due to the fertilizers, not microbes. Unfortunately, we did not evaluate any microbial product without additional fertilizer, but because no microbial product with fertilizer consistently outperformed the fertilizer alone, it is doubtful that a microbialonly product would have performed any better. Also, the purpose of the study was to evaluate commercially available microbial inoculants as they would be used in a palm nursery, and such nurseries would continue their normal fertility program.

Although the difference in $\mathrm{P}$ status for the two soils was small, soil P status did have a significant effect on height and leaf number for both palm species. This suggests that the palms may have been P-limited and that the small amounts of $\mathrm{P}$ in the products applied at transplanting and for maintenance were insufficient to overcome the $\mathrm{P}$ deficiency in this soil. This should have been the ideal situation to observe the benefit from AM fungi. However, when differences among treatments were observed, the high rate of $8 \mathrm{~N}-0.9 \mathrm{P}-10 \mathrm{~K}$ always had growth parameters better or equivalent to the treatments with AM fungal inoculants.

In the vast majority of studies (Blal et al., 1990; Fisher and Jayachandran, 2008; Jaizme-Vega and Diaz-Perez, 1999; Janos, 1977; Morte and Honrubia, 2002; Sanni, 1981; Widiastuti and Tahardi, 1993), palms have responded positively to the addition of AM fungal inoculum, even when planted into nonsterile field soil. However, none of the previous studies with palms used commercial AM fungal inoculum. Instead, researchers produced inoculum on other host plants or inoculated with AM fungal spores obtained from native soil. In other words, the inoculums were composed of natural materials and were not formulated with any carriers (natural or chemical) or fertilizers, as were the commercial products used in our study. Neither did they store or ship their AM-fungal inoculum. Thus, perhaps we did not observe a response to the commercial AM fungal products because the AM fungi were not viable. In retrospect, we should have conducted a parallel study using an annual crop, such as corn (Zea mays), to examine AM fungal inoculum viability, especially because there were issues regarding presence or absence of other fungi and bacteria in the commercial products. A recent study by Corkidi et al. (2004) examined 10 commercial (i.e., formulated) AM fungal products, and three did not infect the corn seedlings used in the bioassay. We do not believe that addition of fertilizers, including chemical fertilizers, is the cause for lack of palm response to AM fungal inoculums, as previous studies with palms usually demonstrated an additive effect between chemical 
Table 5. Percentage of palm root length with fungal hyphae, arbuscules, and vesicles at 24 months after transplanting queen palm and mexican fan palm into phosphorus $(P)$-deficient and P-sufficient soil.

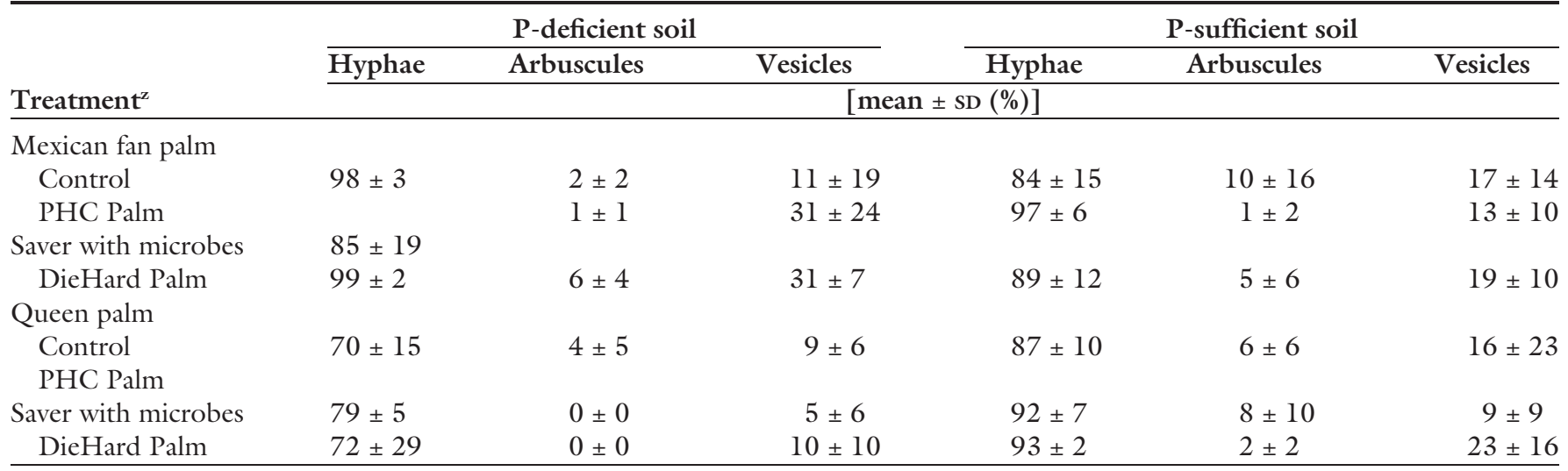

${ }^{2}$ PHC Palm Saver with microbes (Plant Health Care, Pittsburgh, PA), DieHard Palm (Horticultural Alliance, Sarasota, FL).

fertilizers and AM fungal inoculums (Blal et al., 1990; Bovi et al., 2000; Morte and Honrubia, 2002; Sanni, 1981). It is possible that the fertilizer salts killed the AM fungi directly. If this is true, then companies that formulate mycorrhizal products (e.g., Plant Health Care or Horticultural Alliance) should reconsider the addition of fertilizer salts to their commercial products.

Mycorrhizal analysis of the palm roots at transplanting showed queen palm with no mycorrhizal colonization, while mexican fan palm had an average $13.5 \%(\mathrm{SD}=1.3)$ mycorrhizal colonization. The same nursery supplied both palm species. Because palms are often transferred between nurseries during the production process (liners to various size containers), a nursery would not know whether palm seedlings or juveniles had been previously treated with AM-fungal inoculum. Furthermore, it is possible that container-grown palms could become infected with AM fungi naturally, especially if any soil or sand had been used in the potting mix.

Because there appeared to be no response to AM-fungal inoculum, only three transplant treatments were examined for mycorrhizal colonization at 24 months; control, PHC Palm Saver with microbes, and DieHard Palm. Use of thin, second and third order roots proved to be informative regarding mycorrhizal colonization in the field. The percentage of palm root colonization by fungal hyphae for the selected treatments is shown in Table 5 , as are values indicating percentage of root length with arbuscules or vesicles. For both palm species, the percentage of roots with arbuscules was very low, 10\% or less, and was highly variable. The percentage of roots with vesicules was greater (but also highly variable), with more found in association with the mexican fan palm than with queen palm. While AM-fungal hyphae are important in nutrient uptake from the soil, arbuscules are the principle site of nutrient transfer from the fungus to the plant. Vesicles accumulate storage products and form after arbuscules (Harrison, 1997).

Fungal hyphae observed in roots cannot be assumed to be mycorrhizal, but viewing roots with a compound microscope rather than a dissecting scope provides a better method for differentiation (McGonigle et al., 1990). If one assumes the hyphae observed were AM fungal hyphae, then mycorrhizal colonization was quite high for both species on both soil types for fertilized and unfertilized treatments, and implies that AMfungi were naturally present in the soil and the soil AM-fungi may have been the fungi that colonized the palm roots rather than the AM-fungi added as inoculum. If one uses only arbuscules as an indication of AM fungal colonization, then the addition of AM-fungal inoculums did not increase colonization over the control treatment, and colonization was quite low $(\leq 10 \%)$. Similar results have been observed in field-grown strawberry (Fragaria xananassa) inoculated with commercial AM fungal products, including two products used in our study, where levels of AM fungal colonization were the same whether the strawberry plants were treated with AM fungal products or not (Bull et al., 2005).

In conclusion, these data suggest that transplant treatments can influence palm growth initially, but if all palms are subsequently given similar maintenance fertilization, these initial differences eventually become less pronounced (mexican fan palm) or disappear completely (queen palm). After 2 years, none of the microbial inoculants significantly improved the growth of either species over that of similarly fertilized but uninoculated palms.

\section{Literature cited}

Al-Whaibi, M.H. and A.S. Khaliel. 1994. The effect of $\mathrm{Mg}$ on $\mathrm{Ca}, \mathrm{K}$ and $\mathrm{P}$ content of date palm seedlings under mycorrhizal and non-mycorrhizal conditions. $\mathrm{Myco-}$ science 35:213-217.

Artursson, V., R.D. Finlay, and J.K. Jansson. 2006. Interactions between arbuscular mycorrhizal fungi and bacteria and their potential for stimulating plant growth. Environ. Microbiol. 8:1-10.

Blal, B., C. Morel, V. Gianinazzi-Pearson, J.C. Fardeau, and S. Gianinazzi. 1990. Influence of vesicular-arbuscular mycorrhizae on phosphate fertilizer efficiency in two tropical acid soils planted with micropropagated oil palm (Elaeis guineensis Jacq.). Biol. Fertil. Soils 9:43-48.

Bovi, M.L.A., M.L.S. Tucci, S.H. Spiering, and G. GodoyJr 2000. Biomass accumulation and arbuscular mycorrhizal colonization in pejibaye (Bactris gasipaes Kunth) as a function of NPK fertilization. Acta Hort. 513:153-167.

Broschat, T.K. 2005. Fertilization of field-grown and landscape palms in Florida. Univ. Florida Environ. Hort. Dept. Circ. EP261. 
Bull, C.T., J. Muramoto, S.T. Koike, J. Leap, C. Shennan, and P. Goldman. 2005. Strawberry cultivars and mycorrhizal inoculants evaluated in California organic production fields. Online Crop Mgt. Doi: 10.1094/CM-2005-0527-02RS.

Carillo, L., R. Orellana, and L. Varela. 2002. Mycorrhizal associations in three species of palms of the Yucatan Peninsula, Mexico. Palms 46:39-46.

Corkidi, L., E.B. Allen, D. Merhaut, M.F. Allen, J. Downer, J. Bohn, and M. Evans. 2004. Assessing the infectivity of commercial mycorrhizal inoculants in plant nursery conditions. J. Environ. Hort. 22:149-154.

Council on Soil Testing and Plant Analysis. 1992. Reference methods for soil analysis. Council on Soil Testing and Plant Analysis, Athens, GA.

Elliott, M.L. and T.K. Broschat. 2002. Effects of a microbial inoculant on plant growth and rhizosphere bacterial populations of container-grown plants. HortTechnology 12:222-225.

Fisher, J.B. and K. Jayachandran. 1999. Root structure and arbuscular mycorrhizal colonization of the palm Serenoa repens under field conditions. Plant Soil 217:229-241.

Fisher, J.B. and K. Jayachandran. 2005. Presence of arbuscular mycorrhizal fungi in south Florida native plants. Mycorrhiza 15:580-588.

Fisher, J.B. and K. Jayachandran. 2008. Beneficial role of arbuscular mycorrhizal fungi on Florida native palms. Palms 52:113-123.
Gianinazzi, S. and M. Vosátka. 2004. Inoculum of arbuscular mycorrhizal fungi for production systems: Science meets business. Can. J. Bot. 82:1264-1271.

Gould, W.D., C. Hagedorn, T.R. Bardinelli, and R.M. Zablotowicz. 1985. New selective media for enumeration and recovery of fluorescent pseudomonads from various habitats. Appl. Environ. Microbiol. 49:28-32.

Harrison, M.J. 1997. The arbuscular mycorrhizal symbiosis: An underground association. Trends Plant Sci. 2:54-60.

Jaizme-Vega, M.C. and M.-A. DiazPerez. 1999. Effect of Glomus intraradices on Phoenix roebelenii during the nursery stage. Acta Hort. 486:199-202.

Janos, D.P. 1977. Vesicular-arbuscular mycorrhizae affect the growth of Bactris gasipaes. Principes 21:12-18.

Lupwayi, N.Z., P.E. Olsen, E.S. Sande, H.H. Keyser, M.M. Collins, P.W. Singleton, and W.A. Rice. 2000. Inoculant quality and its evaluation. Field Crops Res. 65:259-270.

McGonigle, T.P., M.H. Miller, D.G. Evans, G.L. Fairchild, and J.A. Swan. 1990. A new method which gives an objective measure of colonization of roots by vesicular-arbuscular mycorrhizal fungi. New Phytol. 115:495-501.

Morte, A. and M. Honrubia. 2002. Growth response of Phoenix canariensis to inoculation with arbuscular mycorrhizal fungi. Palms 46:76-80.

Núñez-Castillo, O. and F.J. AlvarezSanchez. 2003. Arbuscular mycorrhizae of the palm Astrocaryum mexicanum in disturbed and undisturbed stands of a Mexican tropical forest. Mycorrhiza 13:271-276.

Ogden, R.J., F.A. Pokorny, and H.A. Mills. 1987. Elemental status of pine bark-based potting media. Hort. Rev. (Amer. Soc. Hort. Sci.) 9:103-131.

Sanni, S.O. 1981. Vesicular-arbuscular mycorrhiza in some Nigerian soils. Effect of Gigaspora gigantea on the growth of oil palm seedlings (Elaeis guineensis L.), p. 133-138. In: S.O. Emejuaiwe, O. Ogunbi, and S.O. Sanni (eds.). Global impacts of applied microbiology, 6th Intl. Conf., Academic Press, London.

St. John, T.V. 1988. Prospects for application of vesicular-arbuscular mycorrhizae in the culture of tropical palms. Adv. Econ. Bot. 6:50-55.

University of Florida. 2008. Florida Automated Weather Network. 25 Sept. 2008. <http \\fawn.ifas.ufl.edu/data/ reports $/>$.

Vierheilig, H., A.P. Coughlan, U. Wyss, and Y. Piché. 1998. Ink and vinegar, A simple staining technique for arbuscularmycorrhizal fungi. Appl. Environ. Microbiol. 64:5004-5007.

Widiastuti, H. and J.S. Tahardi. 1993. Effect of vesicular-arbuscular mycorrhizal inoculation on the growth and nutrient uptake of micropropagated oil palm. Menara Perkebunan 61:(3):56-60. 